Caligrama, Belo Horizonte, v. 22, n. 1, p. 87-107, 2017

\title{
Os dois primeiros livros de poesias de Machado de Assis: seus títulos, suas semelhanças e diferenças - interrelações
}

\section{The first two poetry books by Machado de Assis: their titles, their similarities and differences - interrelations}

José Américo Miranda ${ }^{1}$

Universidade Federal do Espírito Santo, Vitória, Espírito Santo / Brasil

CNPq/FAPES

plkx23@gmail.com

Resumo: Este artigo examina os dois primeiros livros de poesia publicados por Machado de Assis - Crisálidas, em 1864, e Falenas, em 1870 - no que eles têm de semelhanças e de diferenças. Ambos os livros têm sido interpretados pela crítica em função de dados biográficos, porque os temas abordados nos poemas estão intimamente relacionados com a vida do poeta. No segundo livro, que é dividido em quatro partes, entretanto, apenas a primeira se presta a esse tipo de interpretação. Pela maneira com que seus títulos se relacionam, este artigo propõe que o título de Falenas só se aplica, com propriedade, à primeira parte do segundo livro.

Palavras-chave: poesia brasileira; nacionalismo literário; Machado de Assis.

Abstract: This paper analyses the similarities and differences that exist between the first two books of poetry published by Machado de Assis - Crisálidas, in 1864, and Falenas, in 1870. Both books have been interpreted critically on the basis of biographical data, because the

\footnotetext{
${ }^{1}$ Pesquisador DCR (Desenvolvimento Científico Regional) do CNPq, com apoio da Fundação de Amparo à Pesquisa e Inovação do Espírito Santo (FAPES), junto ao Programa de Pós-Graduação em Letras (PPGL) da Universidade Federal do Espírito Santo (UFES).
} 
themes addressed in the poems are closely related to the life of the poet. In the second book, which is divided into four parts, however, only the first part lends itself to this kind of interpretation. By the way their titles relate to one another, this article proposes that Falenas is an appropriate title only for the first part of the book.

Keywords: Brazilian poetry; literary nationalism; Machado de Assis.

Recebido em: 19 de abril de 2017.

Aprovado em: 3 de junho de 2017.

\section{Os títulos e as obras}

A propósito de Crisálidas (1864) e Falenas (1870): vistos assim, a distância, como os vemos hoje, os títulos dos dois primeiros livros de Machado de Assis parecem bem ajustados e corretos. No mundo dos organismos e no tempo, a crisálida precede à falena; as metáforas dos títulos, aplicadas aos poemas de cada livro, correspondem a etapas sucessivas na história do autor - cada coisa parece em seu lugar. Entretanto, o modo como se vê qualquer coisa no mundo depende, entre outras coisas, do lugar de onde se mira o objeto, da perspectiva que se adota ao visá-lo. A aparência de naturalidade que nos faz hoje aceitar os títulos desses dois livros, pela relação que um tem com o outro, nem sempre foi pacificamente aceita.

Entre as críticas feitas a Crisálidas, na época de sua publicação, algumas diziam respeito ao título do livro. Já na "Conversação preliminar", que trazia o título de "O poeta e o livro", Caetano Filgueiras, amigo de Machado de Assis, o chamou de "falso", viu nele uma "contradição", porque "Crisálida é ninfa, é princípio de transformação, aurora de existência, semente de formosura [...] e os versos de Machado de Assis são gemas cintilantes, vida espalmada, flores e sorrisos." E disse mais:

$\mathrm{Na}$ mortalha informe e incolor do casulo a graça está em problema, o movimento em risco: os versos de Machado de Assis só guardaram de ninfa a beleza e o dom da aeredade! São fúlgidas borboletas que adejam sobre todas as flores 
d'alma, revelando a quem a contempla a perfeição da criatura e o gênio do criador. Não são, pois, crisálidas; se o fossem não seria o autor poeta, e Machado de Assis, leitor, é poeta! (FILGUEIRAS, 1864, p. 11-12).

Em resenha publicada ainda em 1864, M. A. Major, que discordou de Filgueiras no tocante à eloquência, harmonia e exatidão dos versos de Machado de Assis - o que afirmou ser "exageração de benevolência" (MAJOR, 1864, p. 213-214) -, concordou com ele na opinião sobre a inadequação do título à obra: "É por isso mesmo que supomos haver um erro, um quê de falso na aplicação do título, porque as poesias de Machado de Assis assemelham-se antes ao doidejar incessante da borboleta do que ao estado imóvel da lagarta (MAJOR, 1864, p. 208-209).

A inquietação do poeta, a liberdade de sua musa, a fascinação pela poesia de outras partes do mundo, tudo isso foi motivo de sua reprovação - e escondia, para vir à tona mais tarde, principalmente depois do aparecimento de Falenas, a expectativa, por parte da crítica, de que ele produzisse poesias de assuntos nacionais. Tudo isso guarda relação com as reformas a que o poeta submeteu seus dois primeiros livros quando os preparou para a segunda edição, em 1901, nas suas Poesias completas. Nessa ocasião, não só ele eliminou numerosos poemas desses dois livros, mas agiu também - e isso é tão importante quanto as supressões que fez - para reorganizar os livros, reordendo-lhes os poemas, dando-lhes outra feição, outra composição.

\section{Crisálidas e suas duas primeiras edições}

Quando preparou seu primeiro livro de poesias para a segunda edição, ao incluí-lo nas Poesias completas, publicadas em 1901, Machado de Assis o passou em revista, aprimorando-lhe a forma. Desde a primeira edição, o livro já apresentava sinais do desejo do poeta de que sua forma tivesse contornos definidos, que lhe dessem uma feição peculiar e acabada. Entre esses sinais encontram-se os poemas inicial e final, "Musa consolatrix" e "Última folha", respectivamente. No primeiro deles, em interlocução com a Musa, o poeta expôs a concepção que tinha da poesia: 
Que a mão do tempo e o hálito dos homens

Murchem a flor das ilusões da vida,

Musa consoladora,

É no teu seio amigo e sossegado

Que o poeta respira o suave sono

(ASSIS, 1864, p. 21).

Até o fim da vida, como se pode constatar na correspondência do poeta com seus amigos, especialmente com Mário de Alencar e Carlos Magalhães de Azeredo, Machado de Assis recorreu à ideia da criação literária em geral, e da criação poética em particular, como alívio e consolo para as dores do mundo. Se o poeta abre o seu primeiro livro de poesias com esse poema, ele o fecha também em diálogo com a Musa. Ao final do volume, no poema intitulado "Última folha", depois de ter passado por uma experiência amorosa que o exauriu e que ficou registrada no poema mais famoso do livro, "Versos a Corina", o poeta pede à Musa que desça das alturas onde tem morada:

Musa, desce do alto da montanha

Onde aspiraste o aroma da poesia,

E deixa ao eco dos sagrados ermos

A última harmonia.

\section{$[\ldots]$}

Vês? Lá no fundo o vale árido e seco

Abre-se, como um leito mortuário;

Espera-te o silêncio da planície,

Como um frio sudário

(ASSIS, 1864, p. 155-156).

Esses dois poemas, os únicos em que o poeta se dirige à Musa, ao abrir e ao fechar o volume, dão contornos claros ao livro - eles foram compostos, com certeza, para ocuparem essas posições. O conjunto das poesias distribuídas entre eles, entretanto, não revela uma organização previamente arquitetada. Entre esses dois textos, o livro, em sua primeira edição, trazia 25 poemas do autor, e um de seu amigo Faustino Xavier de Novais. No conjunto, havia um pouco de tudo: poemas líricos breves, em metros curtos, como "Visio", "Quinze anos", "Stella", "Erro", "Sinhá"; poemas de assunto bíblico e religioso, como "O dilúvio", "Fé", "A caridade"; poemas satíricos, como "Os arlequins" e as "As ventoinhas"; 
poemas de cunho filosófico, que já anunciavam o poeta pessimista da maturidade, como "No limiar" e os "Os dous horizontes"; um poema elegíaco, em homenagem à jovem atriz Ludovina Moutinho, composto por ocasião de sua morte; alguns outros poemas relacionados e dedicados a amigos; dois poemas de conotações ideológicas e políticas, um sobre o imperador imposto ao México pelas potências europeias, outro sobre o domínio da Polônia pela Rússia - ambos acontecimentos da época, com repercussões políticas internacionais; e seis poemas traduzidos (de Musset, André Chénier, Alexandre Dumas Filho, Mme. Émile de Girardin, Mickiewicz e Heinrich Heine). "Versos a Corina", o mais famoso e mais extenso poema do livro, testemunhava uma experiência amorosa recente e malsucedida do poeta. Ele próprio o confessou em carta, anos mais tarde, a sua futura esposa, quando ainda eram noivos, estando ele no Rio e ela em Petrópolis (ASSIS, 1994, v. 3, p. 1029).

Diante dessa diversidade de temas e formas, e intitulando-se Crisálidas o livro, a imagem do "doidejar incessante da borboleta" foi empregada por Amaral Tavares $(1864$, p. 1) para caracterizar a obra, e a das "fúlgidas borboletas que adejam sobre todas as flores d'alma" foi usada por Caetano Filgueiras (1864, p. 12) para se referir aos poemas. Amaral Tavares mencionou ainda as crônicas que Machado de Assis publicava naquela época no Diário do Rio de Janeiro sob o título de "Ao acaso", para assinalar a diversidade existente nos poemas. Naquelas crônicas encontrou ele um símile para dar a ver o que se passava em Crisálidas:

Mas, por que razão há de o poeta deixar entrever a figura do folhetinista leviano que doudeja ao acaso por entre as anedotas e os acontecimentos, as notícias e as facécias, os sorrisos e as lágrimas, tocando apenas em cada um, sem se demorar em nenhum, esquecendo na linha seguinte o que escrevera na anterior? (TAVARES, 1864, p. 1)

Conforme se vê, trata-se da já mencionada preocupação com a livre movimentação do poeta, que saltava de um assunto a outro, sem que entre eles houvesse um nexo necessário. Nenhum dos críticos daquele tempo afirmou claramente, mas o fundamento dessa crítica reside no fato de que tal comportamento (excessivamente livre) distanciava o livro da possibilidade de ele ter uma unidade. Eles, entretanto, reconheceram no lirismo a grande força do poeta. Para os críticos da época, Machado de Assis era um poeta essencialmente lírico. 
Esta característica - de livro heterogêneo - continuou sendo apontada ao longo do século XX. Em texto redigido em 1959 para servir de prefácio à edição crítica das Poesias completas de Machado de Assis (mas que não foi aproveitado nela), Antônio Houaiss observou que "as unidades integrantes dos quatro volumes [que constituem as Poesias completas] têm uma relativa autonomia, já que não constituem partes de um todo previamente concebido como unidade maior" (HOUAISS, 1979, p. 203). Houaiss, como se vê, reconheceu esse mesmo traço em todos os quatro livros de poesias do autor. Jean-Michel Massa, por sua vez, reconheceu a dificuldade de aferir o valor da obra, tal como ela apareceu em 1864, devido ao seu caráter "compósito": "Não encontramos um fio de Ariadne na sequência das vinte e duas peças de Crisálidas, vinte e oito, se contarmos as traduções" (MASSA, 1971, p. 389).

A vida de poeta de Machado de Assis correu paralela a sua vida de jornalista; ele publicava poesias na imprensa periódica desde 1854, e foi pela poesia que entrou na vida de jornais e revistas. A variedade presente em sua obra poética, evidentemente, guarda íntima relação com essa circunstância. Um dos poemas de seu primeiro livro, "Horas vivas", chegou a ser publicado pela primeira vez como parte de uma crônica, fingidamente atribuído a "um poeta" (ASSIS, 1959, p. 76-77).

Das poesias que reuniu em Crisálidas, cerca de metade já havia sido divulgada; e a peça mais antiga incluída no livro data de 1858 -é o poema "Monte Alverne". Este mesmo fato, da divulgação das poesias na imprensa antes da divulgação em livro, foi observado por outro crítico, que também fez restrições, por causa disso, ao título da obra: "As Crisálidas são um livro elegante, cujo título, no nosso entender, não está justificado, porque as produções reunidas em um feixe despossuem o mérito da novidade" (LEITÃO, 1866, p. 380).

Em consideração que partia de ponto de vista semelhante, mas que se fazia acompanhar da observação de que a produção poética do autor já se estendia por 10 anos e contava mais de uma centena de poemas divulgados na imprensa, escreveu Jean-Michel Massa: "Se para a crítica e para o público Crisálidas parece ser a primeira manifestação poética de um jovem talento, em compensação, para o poeta, não acontecia o mesmo. Crisálidas é um ponto de chegada, uma opção e não um ponto de partida" (MASSA, 1971, p. 380).

Tal era o livro em sua primeira edição. Quando o reexaminou, para inclusão nas Poesias completas (1901), o poeta fez nele uma depuração: eliminou 16 dos 28 poemas; permaneceram apenas 12 . Ao fazer isso, 
certamente levou em consideração as críticas que recebera por ocasião do lançamento do livro. Permaneceram nele, predominantemente, os poemas líricos em metros curtos; foram eliminadas as sátiras, as traduções, os poemas de assuntos ligados à religião, os fortemente vinculados a amigos e que traziam dedicatórias a eles.

O gesto do poeta é de fácil interpretação: buscou dar ao livro a unidade que ele não tinha; conservou nele os poemas que o delimitavam (os diálogos com a Musa); eliminou tudo o que lhe perturbava a ordem lírica. Dos poemas vinculados a amigos, só permaneceu no livro, com o título alterado para "Elegia", o poema "A Ludovina Moutinho" - a eliminação do nome da morta conferiu autonomia ao texto, desvinculou-o de seu contexto imediato, e seu potencial universalizante passou ao primeiro plano. Veja-se a reflexão contida nesta estrofe:

\author{
Mas, quando assim a flor da mocidade \\ Toda se esfolha sobre o chão da morte, \\ Senhor, em que firmar a segurança \\ Das venturas da terra? Tudo morre; \\ À sentença fatal nada se esquiva, \\ $\mathrm{O}$ que é fruto e o que é flor. $\mathrm{O}$ homem cego \\ Cuida haver levantado em chão de bronze \\ Um edifício resistente aos tempos, \\ Mas lá vem dia, em que, a um leve sopro, \\ $\mathrm{O}$ castelo se abate, \\ Onde, doce ilusão, fechado havias \\ Tudo o que de melhor a alma do homem \\ Encerra de esperanças. \\ (ASSIS, 1901, p. 24-25)
}

O topos da fragilidade da vida faz lembrar o "monumentum aere perennius" horaciano, que se casa muito bem à ideia da poesia como "musa consolatrix".

$\mathrm{O}$ outro poema fortemente vinculado à vida do poeta que permaneceu na versão definitiva de Crisálidas foi "Versos a Corina". Trata-se do mais longo poema da coleção; foi ele o texto que tornou célebre o livro, ao ponto de Machado de Assis passar a ser referido como "o poeta de Corina" (MASSA, 1971, p. 400-414; LEAL, 2008, p. 90). Ele é, pois, um poema incontornável, que não poderia ter sido excluído do livro - apesar disso, o poeta lhe suprimiu um trecho, os versos finais da terceira parte. O texto é dividido em seis partes que, sequencialmente, 
dão a conhecer um grande amor do poeta, embora o nome da mulher que o inspirou permaneça desconhecido. Na primeira parte, fala o poeta de Corina e da confiança que depositava no tê-la encontrado:

De um júbilo divino os cantos entoava

A natureza mãe, e tudo palpitava,

A flor aberta e fresca, a pedra bronca e rude,

De uma vida melhor e nova juventude.

Minh'alma adivinhou a origem do teu ser;

Quis cantar e sentir; quis amar e viver;

À lus que de ti vinha, ardente, viva, pura,

Palpitou, reviveu a pobre criatura;

Do amor grande, elevado, abriram-se-lhe as fontes;

Fugiram novos sóis, rasgaram-se horizontes;

Surgiu, abrindo em flor, uma nova região;

Era o dia marcado à minha redenção.

(ASSIS, 1901, p. 30-31)

Com o coração cheio de esperanças, na segunda parte do poema, ele faz um exame de sua vida passada, num conjunto de quadras decassilábicas. Eis algumas delas:

Não sei que fogo interno me impelia

À conquista da luz, do amor, do gozo,

Não sei que movimento imperioso

De um desusado ardor minha alma enchia.

Corri de campo em campo e plaga em plaga,

(Tanta ansiedade o coração encerra!)

A ver o lírio que brotasse a terra,

A ver a escuma que cuspisse - a vaga.

Mas no areal da praia, no horto agreste,

Tudo aos meus olhos ávidos fugia...

Desci ao chão do vale que se abria,

Subi ao cume da montanha alpestre.

Nada! Volvi o olhar ao céu. Perdi-me

Em meus sonhos de moço e de poeta;

E contemplei, nesta ambição inquieta,

Da muda noite a página sublime.

(ASSIS, 1901, p. 33-34) 
Depois de uma sequência de doze dessas quadras, o poema muda subitamente de tom, os versos passam a setessílabos, e, no ritmo inquieto desse metro, eis o que acontece:

Mas, tu passaste... Houve um grito

Dentro de mim. Aos meus olhos

Visão de amor infinito,

Visão de perpétuo gozo

Perpassava e me atraía,

Como um sonho voluptuoso

De sequiosa fantasia.

(ASSIS, 1901, p. 35)

Corina se torna a esperança de uma vida feliz para o poeta. Eis o que ela significa para ele (os versos seguintes são já da terceira parte):

Quando voarem minhas esperanças

Como um bando de pombas fugitivas;

E destas ilusões doces e vivas

Só me restarem pálidas lembranças;

$[\ldots]$

Quando assim seja, por teus olhos juro,

Voto minh'alma à escura soledade,

Sem procurar melhor felicidade,

E sem ambicionar prazer mais puro.

(ASSIS, 1901, p. 37)

Já o poeta recebera sinais negativos, que diziam "não" a sua esperança. Na quarta parte, diz ele, em elevados versos alexandrinos:

Tu que és bela e feliz, tu que tens por diadema

A dupla irradiação da beleza e do amor;

E saber reunir, como o melhor poema,

Um desejo da terra e um toque do Senhor;

Tu que, como a ilusão, entre névoas deslizas

Aos versos do poeta um desvelado olhar,

Corina, ouve a canção das amorosas brisas,

Do poeta e da luz, das selvas e do mar.

(ASSIS, 1901, p. 39) 
E seguem-se as canções das brisas, da luz, das águas, das selvas e do poeta. Toda a natureza a celebra: as brisas invejam-lhe as notas de seu canto; a luz natural considera-se inferior à luz dos olhos dela; as águas, comparando-a a Vênus, convidam-na - "vem!"; e as selvas a tomam por Diana. $\mathrm{O}$ aceno das águas é sinal de viagem. O poeta lhe pede que fique:

Ouviste a natureza? Às súplicas e às máguas

Tua alma de mulher deve de palpitar;

Mas que te não seduza o cântico das águas,

Não procures, Corina, o caminho do mar!

(ASSIS, 1901, p. 42)

$\mathrm{Na}$ quinta parte o poeta já reconhece sua derrota, em quintilhas decassilábicas, em que o primeiro verso de cada uma é sempre repetido no final:

Embora fujas aos meus olhos tristes,

Minh'alma irá saudosa, enamorada,

Acercar-se de ti lá onde existes;

Ouvirás minha lira apaixonada,

Embora fujas aos meus olhos tristes.

(ASSIS, 1901, 44)

Por fim, na sexta parte, em grandiloquentes alexandrinos, o poeta reconhece a inutilidade de seu esforço e dá por encerrada sua experiência:

Em vão! Contrário a amor é nada o esforço humano,

É nada o vasto espaço, é nada o vasto oceano!

(ASSIS, 1901, p. 48)

Em seguida ao malogro da experiência amorosa mais intensa experimentada pelo poeta até então em sua vida, vem o poema "Última folha", em que, exaurido, exausto, pede à Musa que se cale.

É praticamente certo que, ao refazer o livro para a segunda edição (nas Poesias completas), eliminando 16 dos 28 poemas que o compunham, reorganizando no livro as peças que restaram, o poeta buscava conferir à obra a unidade que ela não tinha na primeira edição. Essa unidade, ele a buscou nos poemas líricos, os mais elogiados pela crítica do tempo. O dado curioso, nesse procedimento, foi a permanência no livro de dois poemas de cunho político - "Epitáfio do México" e "Polônia". Com isso ficou plantada, bem no centro (no coração) do livro, a semente do mundo grande, do universalismo, do cosmopolitismo 
do poeta, em meio à expressão de suas vivências mais profundas - os "Versos a Corina" são bem o testemunho delas. E, em tal ambiente, não se pode negar que as paixões políticas ajudam a desenhar-lhe o quadro da vida interior, de que o gênero lírico é a expressão.

\section{De Crisálidas a Falenas}

Do "Epitáfio do México", poema de Crisálidas, pode-se puxar um fio que nos conduza às Falenas, pois o quarto poema desse segundo livro de poesias de Machado de Assis, "La marchesa de Miramar", tem relação direta com a aventura mexicana do imperador Maximiliano. Os versos de "Epitáfio do México" são um reflexo do pensamento político de Machado de Assis, o "pensamento de um jornalista sinceramente engajado no liberalismo político, de um militante sincero do antiimperialismo" (MAGALHÃES JÚNIOR, 1981, v. I, p. 257). O poema está composto em quatro sextilhas heptassilábicas, em que os versos ímpares são soltos e esdrúxulos (o que cria, compensatoriamente, uma espécie de rima rítmica), e os pares rimam o segundo com o quarto, em cada estrofe, e o sexto com o sexto da estrofe seguinte. Eis a primeira e a última estrofes:

Dobra o joelho: - é um túmulo.

Em baixo amortalhado

Jaz o cadáver tépido

De um povo aniquilado;

A prece melancólica

Reza-lhe me torno à cruz.

\section{$[\ldots]$}

E quando a voz fatídica

Da santa liberdade

Vier em dias prósperos

Clamar à humanidade,

Então revivo o México

Da campa surgirá.

(ASSIS, 1901, p. 14-15)

Da tragédia nacional do México extrai o poeta uma outra, de alta voltagem lírica, no poema "La marchesa de Miramar", já em Falenas nele, o poeta transpõe para o plano da poesia a realidade vivida pela viúva do imperador Maximiliano, executado no México. No plano poemático, a experiência dela é associada à forte tradição que, passando pela epígrafe 
de Correia Garção, tomada à "Cantata de Dido" (ASSIS, 1901, p. 61)², nos conduz à desventura da rainha de Cartago, narrada por Virgílio nos versos finais do livro IV da Eneida. Eis alguns trechos, que nos dão o roteiro da composição, que tem 106 versos:

De quanto sonho um dia povoaste A mente ambicios,

Que te resta? Uma página sombria, A escura noite e um túmulo recente.

$[\ldots]$

No tranquilo castelo, Ninho d'amor, asilo de esperanças, A mão de áurea fortuna preparara, Menina e moça, um túmulo aos teus dias.

Junto do amado esposo, Outra c'roa cingias mais segura, A coroa do amor, dádiva santa Das mãos de Deus. No céu de tua vida Uma nuvem sequer não sombreava A esplêndida manhã; estranhos eram Ao recatado asilo

Os rumores do século.

$[\ldots]$

Mas o destino, alçando a mão sombria, Já traçara nas páginas da história O terrível mistério.

$[\ldots]$

Viúva e moça, agora em vão procuras

No teu plácido asilo o extinto esposo. Interrogas em vão o céu e as águas. Apenas surge ensanguentada sombra Nos teus teus sonhos de louca, e um grito apenas, Um soluço profundo reboando

Pela noite do espírito, parece

Os ecos acordar da mocidade. (ASSIS, 1901, p. 61-65).

${ }^{2}$ A "Cantata de Dido" é parte do drama "Assembleia, ou Partida". Cf. Os versos da epígrafe machadiana em GARÇÃO, 1778, p. 259. 
Em Falenas - livro que se relaciona, cronologicamente, com período em que Machado de Assis conheceu, ficou noivo e se casou com d. Carolina Novais -, Lúcia Miguel Pereira viu "o único momento em que a obra de Machado tem alguma coisa de desabrochado, dá uma sensação de plenitude". Segundo ela, esse livro "já tem outro tom", os poemas dele "são poesias de amor, de amor feliz, perfumadas pela presensa de Carolina" (PEREIRA, 1988, p. 131; 132). É difícil concordar com tal avaliação, quando se consideram poemas como "Ite, missa est", "Ruínas", "Lágrimas de cera" e mesmo "Luz entre sombras" - que ela cita em apoio a sua tese. Como entender, se se adota a perspectiva dela, versos tão tristes, como estes, de "Sombras":

Quando, assentada à noite, a tua fronte inclinas,

E cerras descuidade as pálpebras divinas,

E deixas no regaço as tuas mãos cair,

E escutas sem falar, e sonhas sem dormir,

Acaso uma lembrança, um eco do passado,

Em teu seio revive?

O túmulo fechado

Da ventura que foi, do tempo que fugiu,

Por que razão, mimosa, a tua mão o abriu?

(ASSIS, 1901, p. 66)

Machado de Assis, na mesma carta, já mencionada, em que se referiu a Corina, praticamente confessa a Carolina que conhecia o drama e as razões que a trouxeram de Portugal ao Brasil, e que nós, até hoje, ignoramos. "Tu pertences ao pequeno número de mulheres que ainda sabem amar, sentir e pensar. Como te não amaria eu? Além disso tens para mim um dote que realça o mais: sofreste." (ASSIS, 1994, p. 1029) - lhe escreveu ele. Os versos de "Sombras" são, sem dúvida, uma alusão a essa circunstância.

Jean-Michel Massa, que estudou essa obra de Machado de Assis, como estudou Crisálidas, observou que, nela, "a felicidade raramente vem sem sombras", e que "certas peças [do livro] fazem diretamente alusão a sofrimentos que parecem ter sido as penas experimentadas pela noiva de Machado de Assis" (MASSA, 1971, p. 600; 601). Wilton Cardoso, por sua vez, lembra outros sofrimentos experimentados pelo próprio autor, como a ruptura definitiva com suas origens, sem os quais seria difícil para o leitor alcançar compreensivamente alguns 
dos poemas do livro (CARDOSO, 1958, p. 53-65). Textos como, por exemplo, "Lágrimas de cera" e "Ite, missa est", dificilmente poderiam ser explicados sem os profundos tormentos relacionados a este gesto de dar as costas ao passado.

\section{Falenas e suas duas primeiras edições}

A essa altura, convém observar que o segundo livro de poesias de Machado de Assis, em sua primeira edição (1870), era dividido em quatro partes - "Vária", "Lira chinesa", "Uma ode de Anacreonte" e "Pálida Elvira", todas elas com o título em frontispício divisório -, e mais: que os poemas mencionados até aqui pertencem todos à primeira parte do livro.

Como para Crisálidas, vale para Falenas a caracterização do livro como algo "compósito". Em texto crítico publicado em 1870, o poeta Luís Guimarães Júnior, reconhecendo a dispersão que caracteriza a obra até mesmo em sua primeira parte, afirmou: "A primeira coleção ["Vária"], como indica o título, é uma série de poesias de diferente gênero e variadas formas" (GUIMARÃES JÚNIOR, 1870, p. 2). E sobre a heterogeneidade do livro como um todo, assim como sobre a relação dele com Crisálidas, escreveu Jean-Michel Massa:

Sob um determinado ponto, Crisálidas e Falenas são gêmeas: a ordem dos textos não parece ligada a uma intenção particular. Pelo menos, as quatro partes que dividem a coleção, Vária, Lira Chinesa, Uma Ode de Anacreonte, Pálida Elvira não parecem corresponder a um plano definido. Vinte e cinco poemas originais se sucedem, em seguida lê-se uma tradução refinada, de vanguarda e, enfim, dois textos importantes, um pelo menos por sua extensão, que parecem dar sentido ao volume. A coletânea adquire, assim, uma dimensão menos pessoal e mais literária. Com Falenas, o talento do poeta saiu do casulo e se instalou no caminho artístico. (MASSA, 1971, p. 599)

Importante por diversas razões, a passagem citada aponta para muitas e diferentes questões, que merecem ser um pouco desenvolvidas.

Em primeiro lugar, a "gemelidade" de Crisálidas e Falenas só é válida para a primeira parte do livro - "Vária". Essa é a parte que contém os "vinte e cinco poemas originais" mencionados por Massa; é nela que os biógrafos buscam poemas e temas que se relacionam com a biografia do autor. 
É nela que se manifesta, em Falenas, aquele "desejo secreto de expansão" (PEREIRA, 1988, p. 126) que Lúcia Miguel Pereira apontou em Crisálidas. Em segundo lugar, a heterogeneidade do livro, sua desorganização interna, não se aplica apenas à totalidade do conjunto; ela se aplica, ainda e especialmente, aos 25 poemas da primeira parte - conforme muito bem assinalado por Luís Guimarães Júnior.

Em terceiro lugar, a dimensão "menos pessoal e mais literária" que a obra assume, se pensada em comparação com o primeiro livro, explica-se - e é real - pelas três partes finais do livro, que contêm poemas excelentemente escritos, verdadeiras obras-primas da poesia brasileira. Da primeira para a segunda parte da obra ocorreu um salto qualitativo fundamental, importantíssimo para o desenvolvimento de toda a obra de Machado de Assis, - tão ou mais importante do que o salto de 1881 -, que consistiu no fato de o poeta ter-se libertado de si mesmo, ter passado das questões da esfera pessoal a questões muito outras, não diretamente relacionadas ao poeta e seus problemas. Na "Lira chinesa" já temos um poeta livre, verdadeiro, acima de si mesmo e do seu tempo.

Por fim (último reparo), a interpretação de Massa (1971, p. 599), de que, por causa dos poemas das últimas três partes, "o talento do poeta saiu do casulo e se instalou no caminho artístico", se é válida (e é), aplica-se ao talento do poeta, à trajetória dele. No tocante aos poemas do livro, a afirmativa demanda certa relativização - conforme se verá no desenvolvimento do raciocínio que se segue.

Com relação ao primeiro dos pontos destacados acima, o da continuidade que Falenas representa em relação ao primeiro livro, é de observar-se - como na relação entre os títulos, que supõe a transformação da lagarta em borboleta - que o estado de espírito do poeta, por aquele tempo, transparece claramente apenas em "Vária". Lúcia Miguel Pereira, que tanto se valeu dos poemas dos dois livros para reconstituir a vida do autor, quando alcança a "Lira chinesa", segunda parte de Falenas, afirma:

E então, já senhor da língua e do metro, refugia-se nas traduções dos chineses, na evocação dos gregos, na arte pela arte, na arte que é "de todas as coisas humanas a única que tem o seu fim em si mesma".

Impõe silêncio ao coração, estanca a fonte da poesia - nele, eminentemente a introversão - vai, durante algum tempo dedicar-se à pura ficção. (PEREIRA, 1988, p. 132) 
É clara, nessa passagem, a compreensão da autora de que a verdadeira poesia emana exclusivamente do "eu"; é clara, do mesmo modo, a ideia de que ficção se faz em prosa. Entretanto, o que se observa em Falenas, da segunda parte da obra em diante, é pura ficção poética. É puro fingimento poético tudo o que vem nas três partes seguintes a "Vária", que nada nos dizem da vida e dos problemas íntimos do poeta.

A "Lira chinesa" é constituída por oito poemas chineses traduzidos de Le Livre de jade, de Judith Walter. Para o francês os poemas foram traduzidos em prosa; porém, Machado de Assis lhes dá forma e rigores compatíveis com a poesia de seu tempo. Nenhum dos poemas foi suprimido pelo autor, quando da segunda edição do livro; apenas a sequência deles foi profundamente alterada. A ordem em que os poemas apareciam na edição de 1870 - 1, 2, 3, 4, 5, 6, 7, 8 - foi alterada para - 3, $4,5,6,2,7,8,1$. Na nova organização dada ao conjunto, os poemas em versos decassílabos, combinados com hexassílabos em todos os casos, ocupam as primeiras seis posições - "O poeta a rir", "A uma mulher", "O imperador", "O leque", "A folha do salgueiro" e "As flores e os pinheiros"; apenas o sétimo foi composto em heptassílabos combinados com tetrassílabos - "Reflexos"; e a sequência é encerrada pelo único poema em versos alexandrinos - "Coração triste falando ao sol".

Veja-se a delicadeza dos versos de "Reflexos", poema que também mereceu a atenção de Cecília Meireles:

REFLEXOS

(Thu-Fu.)

Vou rio abaixo vogando

No meu batel e ao luar;

Nas claras águas fitando,

Fitando o olhar.

Das águas vejo no fundo, Como por um brarnco véu, Intenso, calmo, profundo,

O azul do céu.

Nuvem que no céu flutua, Flutua n'água também;

Se a lua cobre, à outra lua

Cobri-la vem. 
Da amante que me extasia, Assim, na paixão ardente, As raras graças copia

Meu coração.

(ASSIS, 1901, p. 98)

Em nota ao final de Falenas, Machado de Assis dizia serem contemporâneos seus todos os poetas chineses que traduzira (ASSIS, [1870], p. 215). Hoje, sabe-se não ser verdadeira essa afirmativa: o poema "Reflexos", por exemplo, é atribuído a Thu-Fu, poeta do século VIII, "que brilha ainda [hoje] como estrela de primeira grandeza" (GUERRA, 1995, p. 96). ${ }^{3}$

Reside justamente nesse ponto, na passagem de "Vária" para a "Lira chinesa", uma das grandezas do livro: a partir daí o poeta como que se livra de si mesmo e passa a fazer poesia do mais alto valor, despregada, dos pontos de vista referencial e existencial, de sua condição de poeta carioca do século XIX. Tão independentes, tão autônomas, são as peças "Lira chinesa", "Uma ode de Anacreonte" e "Pálida Elvira" - que o poeta não se sentiu na obrigação, quando preparou o livro para sua segunda edição (nas Poesias completas), de suprimir as dedicatórias das partes (poemas) que as tinham ("Uma ode de Anacreonte" é dedicada a Manuel de Melo e "Pálida Elvira", a Francisco Ramos Paz). De Crisálidas, na segunda edição, o poeta eliminou todos os poemas dedicados a amigos.

\section{Algumas observações mais}

A heterogeneidade de Falenas, conforme já observado, não se dá apenas no plano da totalidade; ela o caracteriza, desde o começo, pela variedade de sua primeira seção - e certa desorganização decorre da diversidade. Um outro dado de relativa importância, na compreensão da relação entre os dois livros, é o fato de que, na segunda edição, isto é, nas Poesias completas, Falenas perdeu o título de sua primeira parte - de modo que o título da obra ficou diretamente vinculado aos poemas da primeira seção. As outras - com exceção de "Uma ode de Anacreonte", que, pela peculiaridade de ser um poema dramático, continuou com frontispício divisório - passaram a ter seus títulos na mesma página em que se iniciam os versos. Pode ter havido um quê de motivação econômica nisso tudo; porém, fosse necessário o compartimento de "Vária", o título da seção teria subsistido.

\footnotetext{
${ }^{3}$ Sobre os poetas chineses traduzidos, via francês, por Machado de Assis, ver também KNOWLTON, 1995, p. 81-93; PINTO, 2013, p. 93-106.
} 
Outra observação, ainda, é que apenas da seção "Vária" foram excluídos poemas na segunda edição - como foram excluídos numerosos poemas de Crisálidas. A "Lira chinesa", que foi toda reorganizada na segunda edição, não teve sequer um verso suprimido. Tudo aponta, enfim, para o fato de que em Falenas, apenas os poemas de "Vária" guardam relação de continuidade com o primeiro livro.

O fato é que, se o poeta quis dar unidade a Crisálidas quando eliminou dessa obra mais da metade de seus poemas, com Falenas uma tal tentativa não teria sido possível, porque a obra é irredutível à unidade. A bem dizer, há em Falenas quatro obras poéticas nitidamente separáveis (e que o poeta separou). Poder-se-ia dizer, mesmo, que há quatro livros num só volume. Se a "Lira chinesa" é breve, com seus oito poemas curtos - pode-se alegar que não era comum a edição avulsa de livros de tão pequeno porte naquele tempo; porém, é de notar-se que "Pálida Elvira" excede em três oitavas a Prosopopeia, de Bento Teixeira, obra que tem tido diversas edições avulsas. E "Uma ode de Anacreonte" tem uma extensão que alcança a oitava das treze cenas de Os deuses de casaca - obra esta que teve publicação avulsa (a primeira edição tem cerca de 60 páginas).

Que o interesse pelo "volume" necessário a uma obra para publicação não era estranho ao poeta pode-se constatar no mesmo livro, nos versos de "Pálida Elvira", em que ele diz:

\section{Não me censure o crítico exigente \\ O ser pálida a moça; é meu costume \\ Obedecer à lei de toda a gente \\ Que uma obra compõe de algum volume \\ (ASSIS, [1870], p. 174).}

É verdade que, para os padrões da época, a "Lira chinesa" e "Uma ode de Anacreonte" não alcançavam, sozinhas, a extensão (o "volume") necessária, que justificasse uma publicação avulsa. Muito provavelmente foi o que sucedeu, de modo que se enfeixaram num só volume as quatro obras - "Vária" (contendo as falenas), "Lira chinesa", "Uma ode de Anacreonte" e "Pálida Elvira".

Em outra passagem do mesmo poema, diz o poeta, na caracterização do jovem que chega à residência de Elvira e seu tio: 
Demais, era poeta. Era-o. Trazia

Naquele olhar não sei que luz estranha

Que indicava um aluno da poesia,

Um morador da clássica montanha,

Um cidadão da terra da harmonia,

Da terra que eu chamei nossa Alemanha,

Nuns versos que hei de dar um dia a lume,

Ou nalguma gazeta, ou num volume.

(ASSIS, [1870], p. 180-181).

Os versos referidos na estrofe, em que o poeta chama de Alemanha à terra da poesia - "A terra da poesia é a nossa Alemanha" -, são os versos de "Prelúdio", poema que abre a seção "Vária". Fossem os versos de "Vária" pensados como peças do mesmo volume de "Pálida Elvira", haveria alguma incoerência nesta composição - pois o poeta afirma que os dará (os versos) a público "num volume", que, evidentemente, não seria o mesmo em que estivesse o longo "Pálida Elvira". Pode-se até mesmo especular se o reconhecimento dessa "falha" não teria influído na decisão do poeta de excluir "Prelúdio" da versão final de Falenas. Essa posição, contudo, não removeria a incoerência do sistema da obra, porque, uma vez excluído o poema "Prelúdio", uma vez despublicados esses versos, aquilo que diz o poeta - "versos que hei de dar um dia a lume, / Ou nalguma gazeta, ou num volume" - tornar-se-ia uma incoerência por outro motivo, pois os versos (uma vez que não se encontravam em Falenas) não poderiam ser encontrados pelo leitor em parte alguma. $\mathrm{O}$ poeta, exceto pela inclusão do poema em Falenas, jamais o publicou em qualquer outra obra ou periódico.

Desse conjunto de dados se conclui que o título de Falenas cabe, com propriedade, apenas aos poemas da primeira parte do livro. Se os poemas de Crisálidas são larvas, só os da primeira parte do segundo livro têm com eles relação de continuidade suficiente para merecerem o nome borboletas. E se os poemas da "Lira chinesa" são suficientemente leves, curtos, para serem eventualmente comparados a borboletas, "Uma ode de Anacreonte" e "Pálida Elvira" são longos, volumosos, "pesados" demais para se ajustarem com propriedade àquela metáfora. 


\section{Referências}

ASSIS, M. de. Crisálidas. Rio de Janeiro: B. L. Garnier, 1864.

ASSIS, M. de. Crônicas. Rio de Janeiro: W. M. Jackson, 1959. v. 2: 1864-1867.

ASSIS, M. de. Falenas. Rio de Janeiro: B. L. Garnier, [1870].

ASSIS, M. de. Obra completa. Organização de Afrânio Coutinho. Rio de Janeiro: Nova Aguilar, 1994. $3 \mathrm{v}$.

ASSIS, M. de. Os deuses de casaca. Rio de Janeiro: Tipografia do Imperial Instituto Artístico, 1866.

ASSIS, M. de. Poesias completas. Edição crítica pela Comissão Machado de Assis. Rio de Janeiro: Civilização Brasileira, 1976.

CARDOSO, W. Tempo e memória em Machado de Assis. Belo Horizonte: [s.n.], 1958.

FILGUEIRAS, C. O poeta e o livro. Conversação preliminar. In: ASSIS, M. de. Crisálidas. Rio de Janeiro: B. L. Garnier, 1864. p. 7-20.

GARÇÃO, P. A. C. Obras poéticas de Pedro Antônio Correia Garção. Lisboa: Régia Oficina Tipográfica, 1778.

GUERRA, J. A. de J. A lira chinesa de Machado de Assis. Revista de Cultura, Macau, n. 22, II série, p. 95-100, jan.-mar. 1995.

GUIMARÃES JÚNIOR, L. Estudos literários. Falenas. Diário do Rio de Janeiro, Rio de Janeiro, p. 2-3, 5 fev. 1870.

HOUAISS, A. Estudos vários sobre palavras, livros, autores. Rio de Janeiro: Paz e Terra, 1979.

KNOWLTON, E. C. Machado de Assis e a sua lira chinesa. Revista de Cultura, Macau, n. 22, II série, p. 81-93, jan.-mar. 1995.

LEAL, C. M. O círculo virtuoso: a poesia de Machado de Assis. Brasília: Ludens, 2008.

LEITÃO, F. T. Crisálidas: volume de poesias de Machado de Assis. Revista da Sociedade Ensaios Literários, Rio de Janeiro, n. 10, p. 378384, 5 jun. 1866. 
MAGALHÃES JÚNIOR, R. Vida e obra de Machado de Assis. Rio de Janeiro: Civilização Brasileira, 1981. 4 v.

MAJOR, M. A. Crisálidas (Machado de Assis). Revista da Sociedade Ensaios Literários, Rio de Janeiro, n. 6, p. 207-216, 1 nov. 1864.

MASSA, J-M. A juventude de Machado de Assis. Rio de Janeiro: Civilização Brasileira, 1971.

PEREIRA, L. M. Machado de Assis (Estudo crítico e biográfico). 6. ed. rev. Belo Horizonte: Itatiaia, 1988.

PINTO, M. P. A lira chinesa em trânsito: de Machado de Assis a António Feijó. Scientia Traductionis, Florianópolis, n. 14, p. 93, 2013. Disponível em: <https://periodicos.ufsc.br/index.php/scientia/article/view/19804237.2013n14p93/27402 >. Acesso em: 7 jun. 2017.

TAVARES, A. Crisálidas. A Quintino Bocaiuva. Diário do Rio de Janeiro, Rio de Janeiro, p. 1, 16 nov. 1864.

TEIXEIRA, B. Prosopopeia. Rio de Janeiro: Instituto Nacional do Livro, 1972.

VIRGíliO. Eneida. Tradução de Tasilo Orpheu Spalding. São Paulo: Nova Cultural, 2003.

WALTER, J. Le Livre de jade. Paris: Alphonse Lemerre, 1867. 
